\title{
SOIL AND WATER CONSERVATION MANAGEMENT THROUGH INDIGENOUS AND TRADITIONAL PRACTICES IN ETHIOPIA: A CASE STUDY *MUSHIR Ali ${ }^{1}$ and KEDRU Surur ${ }^{2}$ \\ http://dx.doi.org/10.4314/ejesm.v5i4.3
}

\section{Received 12th May 2012; accepted 12th July 2012}

\begin{abstract}
Soil erosion and related forms, now constitute serious problem in many part of Ethiopia. Particularly in Southern Nation, Nationalities and People Regional State (SNNPRS) situated on high and step-faulted western sides of the Ethiopian rift system. An attempt was made attempted, to identify the traditional and indigenous of soil conservation practices, to assess the socio-cultural, economic system constraints for the implementation and maintenance of conservation practices and to evaluate the performance and identify problems and opportunities in the application of soil conservation practices. The study was conducted in Siliti woreda where on the basis sampling of four highland kebeles were selected and 120 farm households were purposively sampled. There was annual soil loss recorded 114.59 tons/ha/year on the steep slopes. The traditional and indigenous methods were applied and practiced as fallowing land $24.2 \%$, contour ploughing $13.3 \%$, structure of planted tress $7.5 \%$, indigenous drainage ditches $8.3 \%$, contour ploughing $13.3 \%$, leaving crop residues 5\% and Fanya juu bench-like terraces $4.2 \%$ terraces for the soil conservation and management in study area

Key words: Soil erosion, indigenous method, bio-physical factors, productivity, management.
\end{abstract}

\section{Introduction}

Ethiopia is one of the most environmentally troubled countries in the SubSaharan belt. The principal environmental problem in Ethiopia is land degradation in the form of soil erosion, gully formation, soil fertility loss and severe soil erosion (Hurni, 1993). Large parts of the highlands of Ethiopia are severely eroded. The vast majority of the population derives its livelihood from agricultural sectors. This is to mean that under conditions of subsistence agriculture, in both the densely populated highlands and sparsely populated lowland areas of the country, survival is solely linked to the exploitation of land (World Bank, 1996; Gebremedin and Swinton, 2002).

On the other hand, the land and water resource bases of the country are highly threatened by over cropping, overgrazing and over reliance on fuel wood. These have resulted insignificant soil losses and deforestation. It is getting aggravated by unprecedented growth of human and livestock population (Wright, 1984). The cultivation has been becoming more intense and fallowing rare since last 20 years. The basic land resources soil, wood and grass are exploited beyond their capacity to regenerate themselves. Consequently, low level of agricultural production in general and the current food insecurity in particular, witnesses the degree to which the land production has been lowered (Daniel, 1998). The severity of soil erosion in Ethiopia can be attributed to intense rainfall and the rugged and dissected nature of the topography with nearly $70 \%$ of highland having slopes exceeding $30 \%$. This in turn favors soil erosion once the vegetation cover is reduced (Wood, 1990).

Hence, to grapple with the problem of soil erosion massive reforestation and soil and water conservation schemes were launched in Ethiopian. Many generous international donors assisted the program. Since 1960s various conservation strategies have been introduced to enhance agricultural development and rural livelihood (Keeley and Scoones, 2000 cited in Aklilu, 2006). However, the success rate has been minimal. Around US\$ 20 billion was allocated annually during 1980s and 1990s (Azene, 1997). Although the achievements were remarkable in quantitative terms, the impacts of these efforts were far below expectations and land degradation continued to be a serious problem (Admassie, 2000). There are several possible reasons for the failure of past conservation 
interventions. First lack of involvement of farmers in the planning and implementation second, the introduction of the measures did not consider local conservation and farming practice and in many cases did not fit in with traditional methods. Third, since interventions normally include such activities as hillside reforestation, terrace construction etc., which are generally characterized by high costs. Poor farmers couldn't afford to invest much money, time and energy. Finally, the extensive and uniform application of similar soil and water conservation measures disregarded local agroecological and socio-economic variations. It is learnt and recognized by facilitators about indigenous soil conservation measures is very minimal. Conflict between indigenous knowledge that farmers have and learned experience that have been communicated to them widened instead of strengthening the other (Asrat et al., 1996, Yohannes, 1999).

Conservation is defined as the management of a resource in such a way as to assure that it will continue to provide maximum benefit to human over the long run (Taffa, 2002). This implies that maintaining viable species populations, to sustain ecological processes and be responsive to short term and long term environmental changes. The concept varies with the type of the resource whether it is renewable or non-renewable. Therefore, for renewable resources, conservation does not mean reducing the exploitation of the resources below the resources rate of replacement. On the other hand, for nonrenewable resources, conservation is an activity of maintaining an adequate supply of these resources well in to the future. Purpose of natural resource conservation is therefore multi-dimensional out of which humanity secure biological, economic and ecological benefits and ensures his survival (Oslon et al, 2002, cited in Mollo, 2009).

Keeping the view of importance conserving the soil and water resources through traditional and indigenous to improve the fertility and productivity of the lands, the study was conducted with following objectives in soil erosion prone Siliti Woreda, southern part of Ethiopia.

\section{Objectives of the Study}

1. To identify the traditional and indigenous of soil and water conservation practices.

2. To assess the socio-cultural, economic, biophysical system and constraints for the implementation and maintenance of soil and water conservation practices

3. To evaluate the performance and identify problems in soil and water conservation practices.

\section{Geographical Outlook of Study Area}

The study was conducted in Siliti Woreda, in Southern Nation, Nationalities and People Regional State (SNNPRS). The study area is situated on high and step-faulted western sides of the Ethiopian rift system. It is extended $7^{0}$ $82^{\prime}$ and $8^{\circ} 06^{\prime} \mathrm{N}$ latitudes and $38^{\circ} 12^{\circ}$ and $38^{\circ}$ 53 E longitudes far away $147 \mathrm{~km}$ south of Addis Ababa. The total area of the woreda is $531.12 \mathrm{sq} \mathrm{km}$ consisting of population 182874 among 38 kebeles (CSA, 2010). There is average mean annual temperature $18.7^{\circ} \mathrm{C}$ and $1293.3 \mathrm{~mm}$ rainfall, both vary with altitude (Woreda Agricultural and Rural Development Office, 2010).

\section{Data Collection and Methods}

The type of research used is descriptive that deals with quantitative and qualitative approaches. Data collection involved both primary and secondary sources. Secondary data were collected from concerned offices and related to books, journals, official documents. The primary data sources include questionnaires, focus-group discussions, field observation and intensive interviews with sample farmers, and other key informants including zonal and local government officials, development agents and elders. All the necessary data were collected through a sample farm household survey conducted in Jan-Feb, 2011. At the first stage of the survey, informal meetings were undertaken with a sampled kebeles' representatives, in order to know the general social, cultural, and economic situations of the population of the study area. Besides, key informants (farmers, elder people, researchers, experts, women, and development agents) were held to get in depth knowledge and to pretest the questionnaire.

Out of total 38 kebeles, four highland kebeles were randomly selected, where 120 farm households were purposively selected 
using list of all farm households. The selection of sample household was proportional to the total number of households of each kebele. Out of the total sample household heads, 99 were males and the remaining 21 were females (Table 2)

Finally a descriptive statistical procedure of the statistical package for the social sciences (SPSS) was used in analyzing and summarizing the data. The Chi-square test, independent t-test and reliability analyses were used to know the relationship between the dependent and independent variables. The qualitative description was used to describe data acquired through focus group discussions and field observations. Collected data were represented through tables, figures and maps.

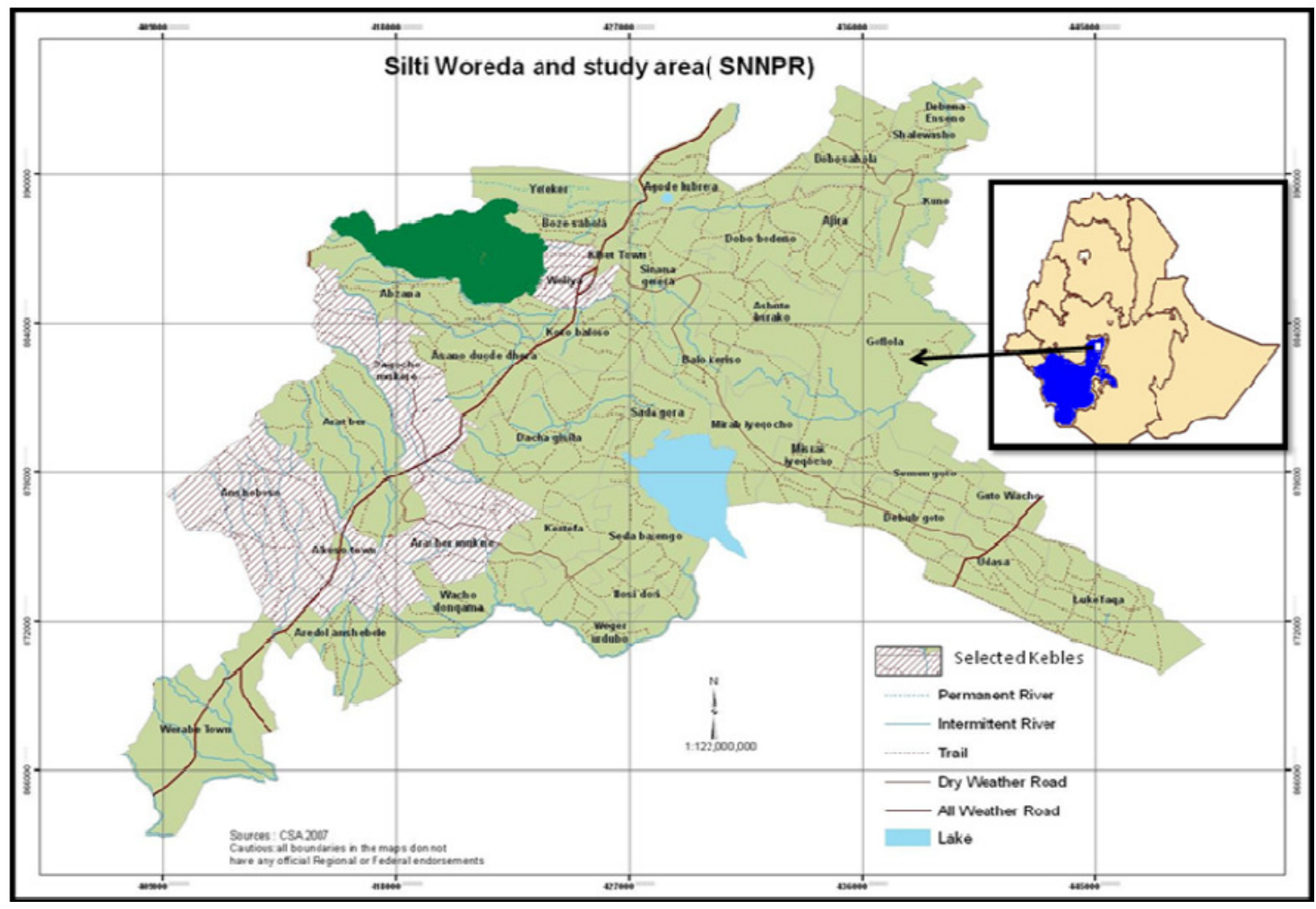

Figure 1 Location of Study Area

\section{Soil Erosion and Conservation Status}

Soil erosion is widespread, but there is considerable variation in the degree of erosion from place to place in the study area. Erosion is most serious in the highlands and middle lands such that most areas are covered with gullies and bare surfaces. These features are good indicators of severe soil erosion in the woreda (Fig.2).

According to the Woreda Agricultural and Rural Development Office (WARDO) annual report, the major causes for soil erosion are the steepness of the land surface, improper land use systems (poor farming practice and expansion of agriculture to sensitive forest and grasslands), poor soil and water conservation practices on farming and eroded lands. So to predict the extent of soil erosion in the area, the study introduces briefly the Universal Soil Loss Equation (USLE), especially, has been modified for the peculiar conditions of the Ethiopian highlands by Hurni (1985). This model has been applied to emphasize the general need of soil conservation measures in the area. The USLE considers several variables affecting the process of soil erosion, like factors of climate, groundcover, land use type and erodibility of soils (Morgan 1995, cited in Steuernagel 2006). 
The Universal Soil Loss Equation (USLE) is given as; $\mathrm{A}=\mathrm{RKLSCP}$

Where, $\mathrm{A}=$ the computed or predicted mean annual soil loss ( $\mathrm{t} / \mathrm{ha} / \mathrm{yr}), \mathrm{R}=$ the rainfall erosivity factor, $\mathrm{K}=$ the soil erodibility factors, $\mathrm{L}=$ the slope length factor, $\mathrm{S}=$ the slop gradient factor, $\mathrm{C}=$ the cropping or ground cover management factor and $\mathrm{P}=$ the erosion control practice factor. The results of the application of the Hurni's modified USLE revealed that in the study area an annual soil loss of about 114.59 tons/ha/year on the steep slopes lying between high and middle altitudes indicate the necessity of soil and water conservation measures implementation as well (Table 3).

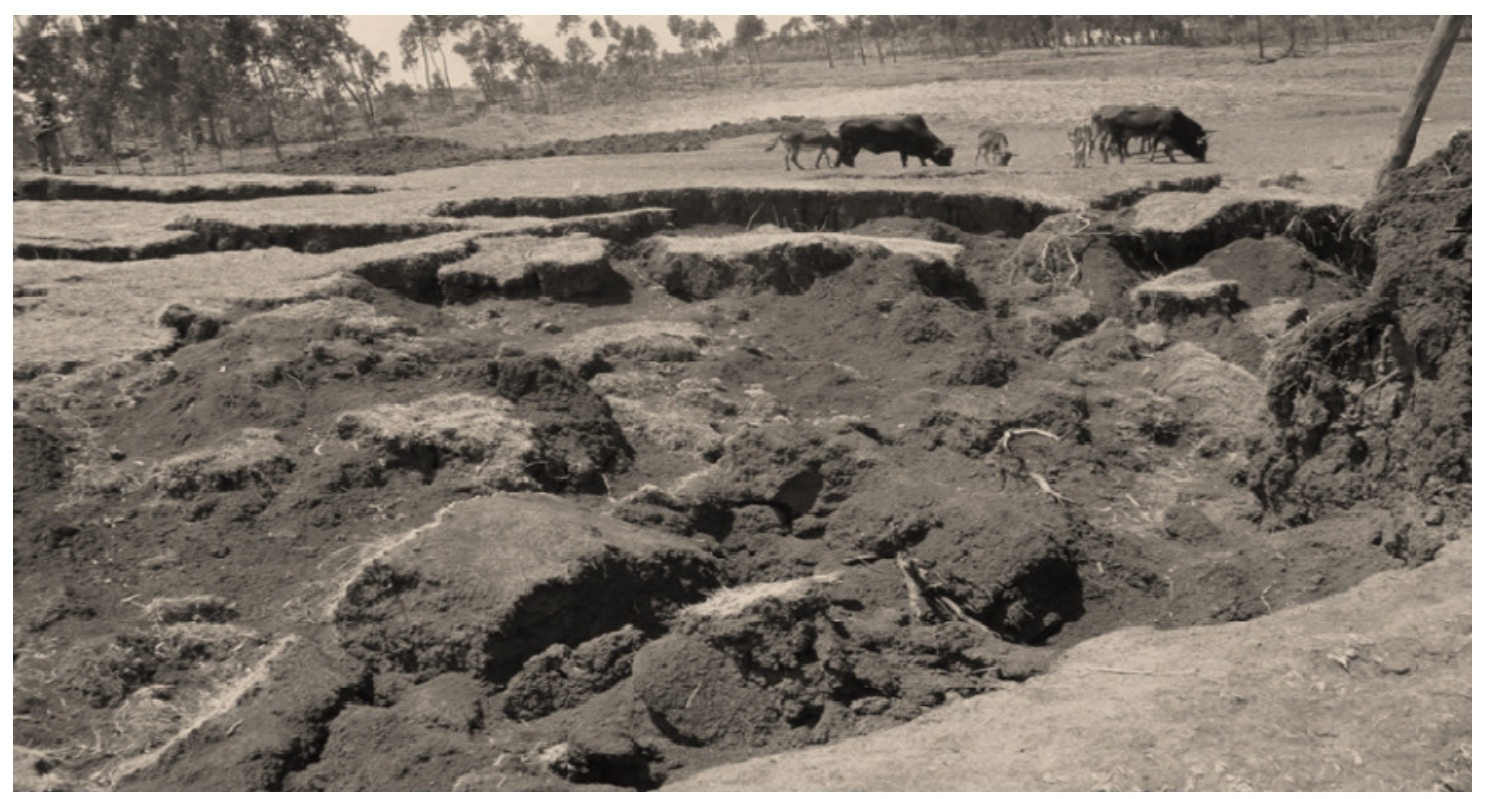

Figure 2 Formation of Active Gullies in A/Mukere

\section{Results and Discussions \\ Soil and Water Conservation Practices in the Study Area}

Farmers' willingness to use soil and water conservation (SWC) practices is largely determined by their knowledge of the problem of soil erosion. The results of the field survey show that about $70 \%$ of the farmers recognized soil erosion problems, and were of the opinion that conservation was necessary. Rill and gully erosion were the dominant forms mentioned by $76 \%$ of the respondents.

Indigenous SWC practices have often been ignored or underestimated by researcher's conservationists and government staff (IFAD, 1992). Whereas, surveying both methods help us to understand farmers' way of thinking about the intervention of the practices (Hudson, 1992) Various erosion control methods used in the area include, plantation of trees, application of manure, cut off drains, soil (stone) bunds, fallowing, contour ploughing drainage ditche and leaving crop residues on the field. The most important conservation structures widely used in the area include, fallowing, distribution of manure and soil (stone) bunds.

Fallow land is a traditional practice of leaving the crop land uncultivated for one or more years for the purpose of recovering soil fertility and minimizing soil loss. About 24\% of the respondents have applied fallowing as a soil conservation measure. This method is used mainly Aratber Mukere and Anshebeso kebeles, where land is plentiful. However, its application is becoming lesser in densely populated than that of other kebeles, because farmers need the land to grow crops every year.

Application of manure in the study area is used by many farmers $(21.7 \%)$ in order to improve the fertility of the soil. Manure 
consisting of animal dung and urine, is the best form of organic fertilizer. Farmers used manure mainly near the homestead. During the focus group discussions with key informant and DAs (Development Agents at kebele level), farmers (especially, those who were poor) have increased the use of manure applied because of the high current price of inorganic fertilizers.

Soil (stone) bund is an embankment or ridge built across a slope along the contour. Soil bunds are made of soil or mud. On moderately sloping areas the farmers construct the soil bunds for erosion control. On steep eroded bare lands stone terraces are most used structures in study area. As it is stated by key informants during focus group discussion the stone terraces are considered effective in erosion control in steeply areas (Fig.4).

In the study area $10.8 \%$ of the respondents have constructed soil and stone bunds (Table 4 ), in the common eroded lands especially around the mountainous area, farmers were constructing bunds because of the cash they would earn from a safety net program.

Contour ploughing is a practice of tilling the land along the contours of the slope in order to reduce the runoff on a steep sloping land. It is used separately or in combination with other conservation structures such as plantation trees and cut- off drains. In the study area from the sample farmers $13.3 \%$ applied the structure in combination with cut off drain (Table 4); it is carried out using the ox-drawn plough. Hence, it is part of the normal farming activity; it needs no extra labor and time for construction. Trees and other non-crop plants such as sisal euphorbia and eucalyptus are planted along the contour sometimes together with other conservation practices (Fig 5). This type of conservation method is applied by $7.5 \%$ of the respondents in order to reduce runoff and conserve the soil and water round the root of the plants. Indigenous and newly introduced trees and shrubs are planted on over used eroded lands to make the land fully productive again. In certain areas, common highly degraded lands are closed off to livestock to protect it from grazing and planted with trees for regeneration.

Drainage ditches are one of the widely used SWC practices in the study area and also known as traditional ditches. These are microchannels constructed on cultivated farms to drain off excess water and control soil erosion. Out of total respondents, $8.3 \%$ applied indigenous drainage ditches. These are low cost measures in which construction is part of the normal ploughing activity. However, unlike the plough furrows, the ditches are made wider and deeper in dimension and usually run diagonally across the field (Fig. 6). Locally farmers in study area, call the drainage ditches "Boye".

Cut off drains are one of the physical structure constructed by digging the soil deep in order to divert the runoff before reaching the farmland. The survey results show that 5\% of the respondents use cut off drains and another $13.3 \%$ used a mix of cut-off drains with contour ploughing. The farmer constructed such structures to prevent loss of seeds, fertilizer and soil due to excessive runoff coming from uplands and dispose the excess water for the field. However, according to farmers' opinion, through time most of these structures are accelerating soil erosion. During a transect walk with DAs gullies associated with the construction of these structure especially, between the boundaries of plots, were commonly observed.

Leaving crop residues on the field after harvest is another traditional practice used by the farmers in the area. The survey results show that only $5 \%$ of the farmers are implementing this type of measure to improve fertility of the soil and there by protect soil from erosion. During the transect walks with key informants, it has been observed that crop residues left on the field in Gewo high altitude areas. However during the discussion with the focus groups, it was noted that because of shortage of animal feed and roof cover for hut, most of the farmers used the crop residue for off plot purposes.

Fanya juu terraces, an improved SWC structures, are made by digging a trench and throwing the soil uphill to form an embankment and over time creates sloping bench-like terraces (Fig.7). The survey results show that $4.2 \%$ of the respondents have used these structures on their fields. Respondents applying these structures explained the advantage of the structures as follows 
$\checkmark \quad$ Bunds hold water and allow it to soak in to the ground reducing run off and causing gullies

$\checkmark$ Soil gradually build up behind the bunds producing a bench terrace

$\checkmark \quad$ This can be built by an individual or by a group

$\checkmark \quad$ Bunds can be used to produce high yield and produce animal feed.

Bio-physical Factors and SWC Practices Farmers' Perception of Soil Erosion as a Problem

Farmer's awareness about the problem and causes of soil erosion as well as its consequences will help to motivate farmers to use soil conservation practices. Accordingly, as the survey result showed $70 \%$ of the interviewed farmers reported from moderate to very severe soil erosion problems on their farmland. While $30 \%$ of them responded that the problem is minor, because most of their farm land is found on gentle slopes (Table 5). The chi-square result $\left(X^{2}=19.06\right.$ at $P<0.05 \mathrm{~d}$. $\mathrm{f}=3$ ) also indicated the existence of significant association between the application of conservation measures and severity of soil erosion problems.

\section{Causes of Soil Erosion and Decline Productivity}

It can be seen that the level of soil fertility is very high on flat land as compared to the other slope degrees. The farmers, who have very fertile lands, possibly do not see the negative effects of erosion on their plots in the short term. Out of the total respondents 53.3\% expressed the opinion that the loss of soil from cultivated fields reduced the depth of the topsoil and led to a reduced production potential.

The slope of the farm land is highly related to the degree of involvement in conservation activities. Farmers living on steep slope are involved more in the continued use of conservation measures than those who own flat or gently sloping farm lands. About $58 \%$ of respondents expressed their farm land slope, moderate to steep (Table 6). The chisquare result of the survey $\left(\mathrm{x}^{2}=17.27\right.$ at $\mathrm{P}<$ $0.05 \mathrm{~d} . \mathrm{f}=3$ ) showed the existence of association between the slope of a farm land and implementation of SWC conservation practices. Thus, the hypothesis that states slope of a farm plot affect soil conservation

practices positively is accepted. A similar conclusion was also forwarded by Aklilu (2006) the effect of steep slopes on the implementation of the stone terraces is due to effectiveness of the measures for erosion control.

Farmers have been asked to indicate the productivity of their farmland overtime, $38.3 \%$ of them indicate the yield in unit area, as decreasing, $16.7 \%$ felt there was no change and $45 \%$ said it was increasing (Table 7). It was noticed that soil erosion was the main reason for decreasing productivity in the yield. The local farmers generally believe that the major causes of soil erosion in their area include erosive rain $(51.7 \%)$ over cultivation $(18.3 \%)$, and cultivation of steep slopes (17.5\%) (Table 8).

\section{Problems Related to SWC Measures}

The major problems related to conservation structures mentioned by the respondents include, source of pests, inconveniency during ox ploughing, reduction of farmland, labour intensiveness, difficulty in implementation, and costliness. During field survey it was recorded that about $31.7 \%$ of respondents indicated soil (stone) bunds reduce farm lands, $23.3 \%$ responded inconveniency during oxen ploughing and $17.5 \%$ revealed labor intensive. Regarding cut-off drains, $36.7 \%, 28.3 \%$ and $21.7 \%$ of respondents reported problems of costly, implementation difficulty, and labour intensiveness, respectively. Concerning, waterway, $39.2 \%, 35.8 \%$ and $11.7 \%$ of the respondents indicated that it is costly, difficult to implement and labour intensive, respectively. As to Fanya juu-32.5\%, $24.2 \%$ and $22.5 \%$ of the farmers responded that it reduce farm lands, require large labor, and inconveniency during oxen ploughing (Table 9).

Farmers were also asked to compare the improved conservation practices with the traditional ones. About $70 \%$ of the respondents indicated that traditional conservation practices perform better in retaining soil. 


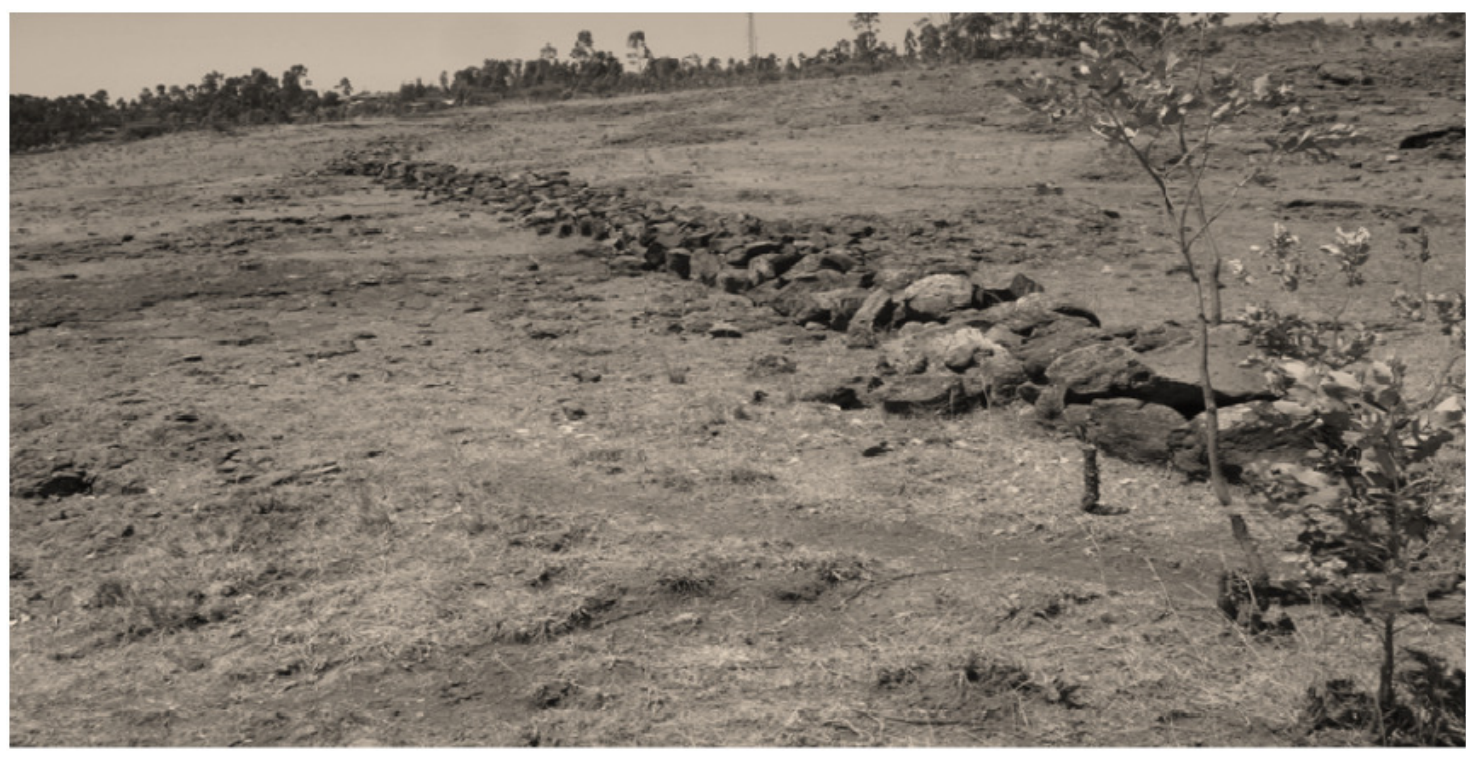

Figure 4 Stone Bunds are Common on Steep Slopes, Anshebeso

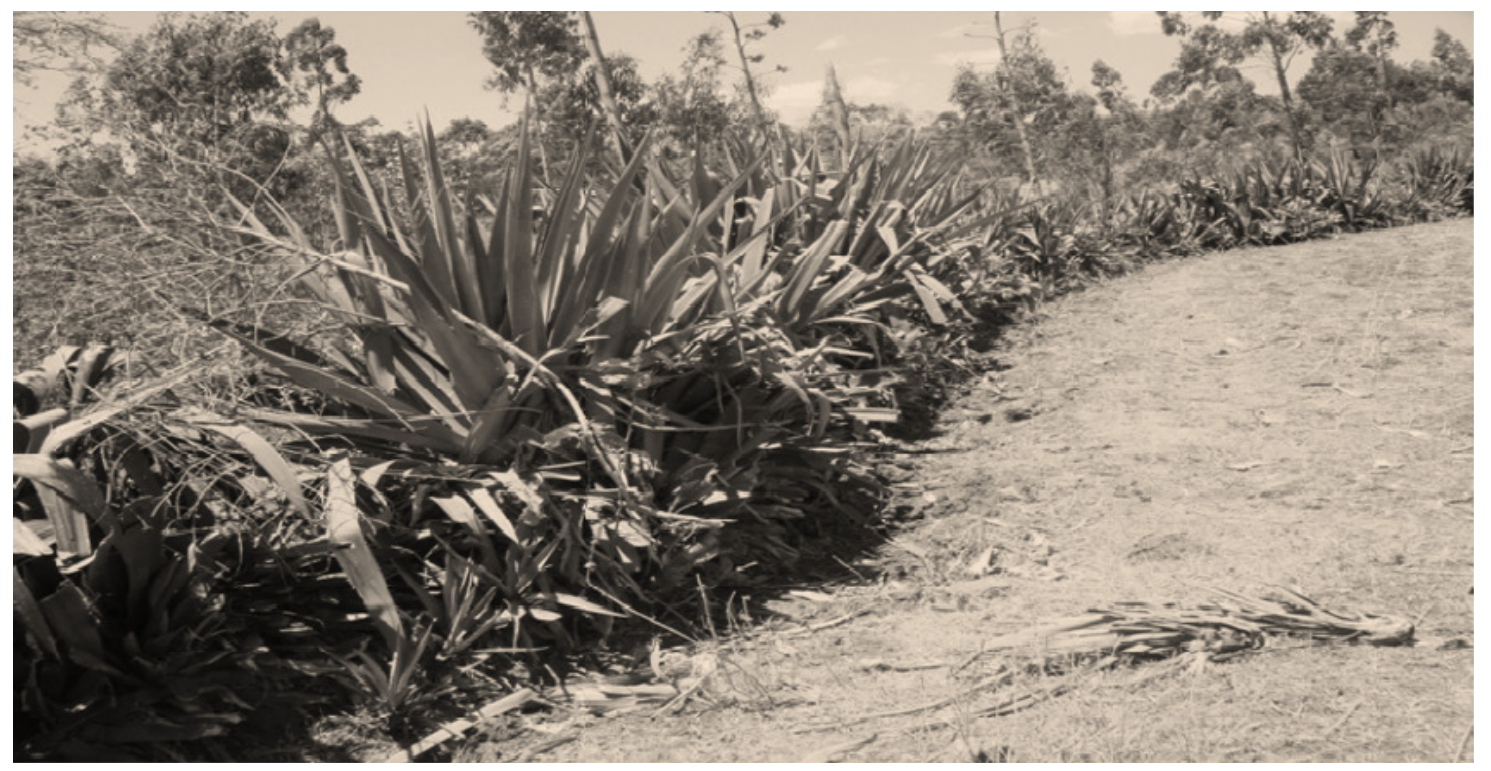

Figure 5 Plantation of Sisal and Euphorbia, D/Mukere 


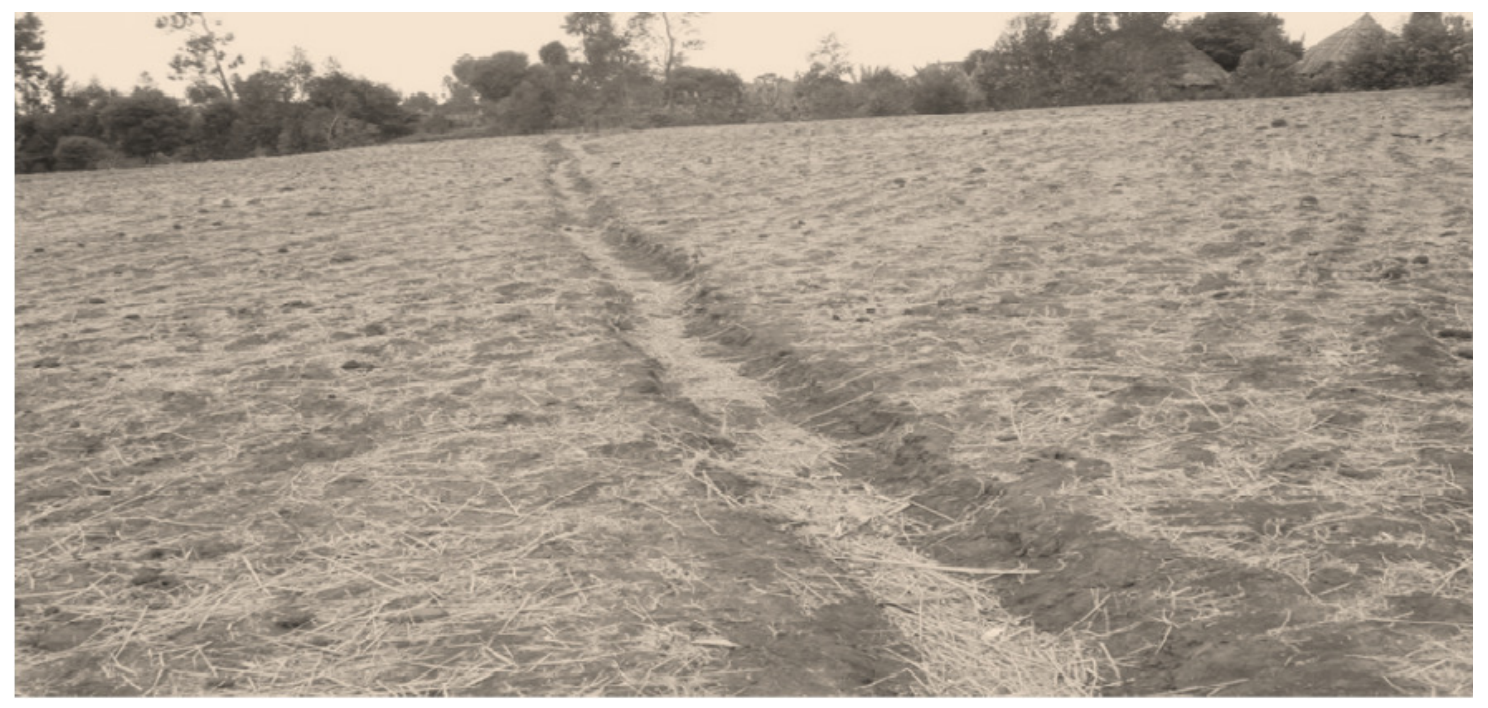

Figure 6 Indigenous Drainage Ditches, Datewezir

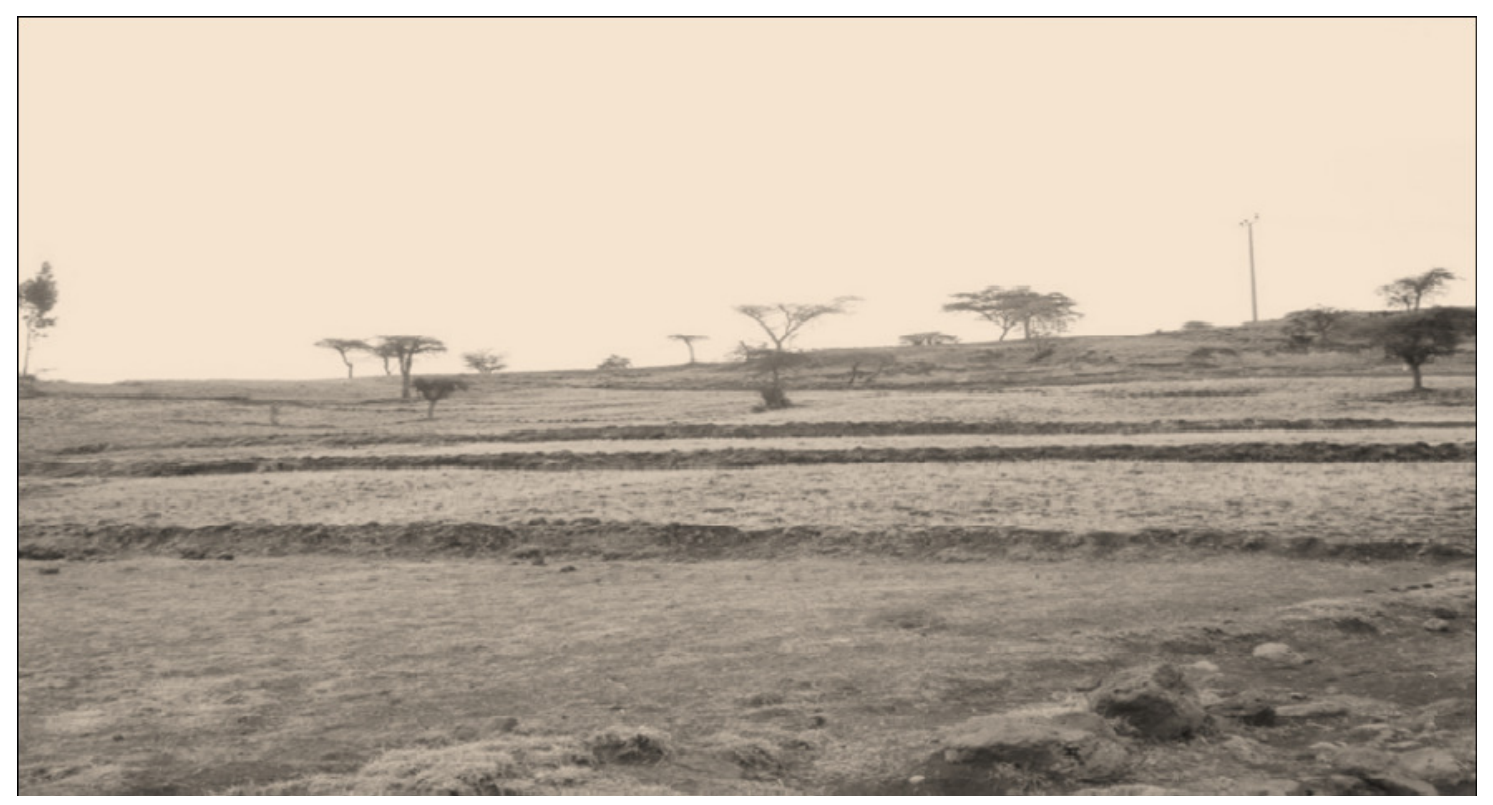

Figure 7 Soil Bunds in Danech 


\section{Conclusions}

It is generally recognized that the Ethiopia highlands experience severe rates of land degradation in the form of soil erosion and nutrient depletion that has constrained agricultural development and food security. The current SWC practices in Southern Ethiopia and to assess the major constraints and opportunities for better conservation intervention. The outcropping of farm lands, formation of rills and gullies, decline of fertility and productivity of soil are some of the identified indicators of soil erosion at the study area.

The most important conservation proactive carried out by farmers as coping strategies to recover the degraded and eroded lands include afforestaton of both indigenous and introduced trees, terracing, construction of check dams closuring and fencing of farm plots, manuring, crop rotation and using agronomic and other structural measures. But lack of vision, poverty and awareness, carelessness, the majority of farmers did not put the methods in to practice. As the result of the study reveal, indigenous soil conservation technologies are considered as effective methods of conservation. Measures such as contour ploughing, manuring, crop rotation, crop residue, cut off drains and ditches as the paramount importance to increase soil fertility, increasing the productive capacity of soil and in arresting soil from erosion. On the contrary, a significant number of the total respondents did not perceive and aware of the effectiveness of such above mentioned indigenous soil and water conservation measure and also most of the farmers, didn't aware of the practices of mulching, mixing and strip-cropping.

Most of the farmers were benefits and practicing of structures such as, soil (stone) bunds, fanya juи and some artificial water ways very well in their farming and grazing plots. These were witnessed as effective and efficient for recovering soil fertility, increasing productivity and decreasing magnitude of erosion. On the contrary, the majority of farmers in the Aratber Mukere and in the upland areas of Danecho Mukere kebele in Gewo sub-kebele, especially females and the poor farmers have not practicing and maintaining the structures on their plots.
Traditional administration and social institutions plays essential role in maintaining strong social linkage and cooperative labor environment. Now-a-days the role as played by the traditional administration and social institutions greatly reduced and consequently the social harmony and the degree of cooperation among the people was threatened. This in turn seriously affects the involvement of the community in the SWC practices with the improved ones and the like; a weakening trend in the overall soil and water conservation practices has been revealed by the study. This weakening trend of the practices has placed their sustainability under serious challenges.

\section{References}

Aklilu, A. (2006). "Caring for the Land: Best Practices in Soil and Water Conservation in Beressa Watershed, Highlands of Ethiopia". Ph.D. Thesis, Wageningen University, Netherlands.

Bekele, W. and Drake, L. (2003). "Soil and Water Conservation Decision Behavior of Subsistence Farmers in the Eastern Highlands of Ethiopia: a case study of the Hunde-Lafto Area", Ecological Economics, Vol.46: 61-81.

Belay, T. (1992). "Farmers' Perceptions of Erosion Hazards and Attitudes towards Soil Conservation in Gunon Wolaita, Southern Ethiopia", Ethiopian Journal of Development Research, Vol. 9:12-21

Biswas, A.K.. (1990). Watershed Management. In: Environmentally sound Water Management, eds N.C. Thanh and T.A. Biswas, Oxford University Press: UK.

Campbell, J. (1991). "Land or Peasants? The Dilemma confronting Ethiopian Resource Conservation". African Affairs, Vol. 90: 5 -21.

Cesen (1986). "Biomass Energy Resources", Ministry of Mines, Addis Ababa, Ethiopia.

Chomba, G. (2004). "Factors Affecting Smallholder Farmers, Adoption of Soil and Water Conservation Practices in Zambia". MSc Thesis, Michigan state University, Department of Agricultural Economics.

Dejene, A. (2003). "Integrated Natural Resources Management to enhance Food Security". FAO, Rome, www.fao.org (accessed 27/10/10). 
Ervin, C.A. and Ervin, E.D. (1982). "Factors Affecting the use of Soil Conservation Practices, Hypothesis, Evidence, and policy Implication". Land Economics, Vol. 58 (3):.277-92.

FAO, (1993). "Natural Resource Degradation in the State of Food and Agriculture". FAO, Rome, www.fao.org (accessed 25/03/11).

Gould, B., William, E., and Richard, M. (1989). "Conservation Tillage, the Role of Farm and Operator Characteristics and the Perception of Soil Erosion". Land Economics, Vol. 65(2): 167-182.

Herweg, K. and Ludi, E. (1999). "The Performance of Selected Soil and Water Conservation Measures-case Studies from Ethiopia and Eritrea". Catena, Vol. (1-2): 99114.

Hurni, H. (1985). "Erosion-Productivity Systems in Ethiopia". Mountain Research and Development, Vol. 8 (2/3):145-51.

Hurni, H. (1988). "Degradation and Conservation of the Resources in the Ethiopia

Table 1 Sample Kebeles and their Characteristics
Highland"., Mountain Research and Development, Vol.13 (2): 123-130

Hurni, H. (1993). "Soil Formation Rates in Ethiopia". AA, FAO /MOA, Joint Project, EHRS, Working Paper No 2.

Kessler, A. (2006). "Moving People-towards Collective Action in Soil and Water Conservation's Experiences from the Bolivian Mountain Valleys". PhD Dissertation, Wageniningen University.

Krishna, R., Bicol, K., Ingrid, I. and Giridhari, S. (2008). "Determinants of Farmers Adoption of Improved Soil Conservation Technology in a Middle Mountain Watershed of Central Nepal". Environmental Management, Springer, New York.

Kruger, Berhanu, F. Gebremichael, Y., and Kejela K. (1996). "Creating an Inventory of Indigenous SWC Measures in Ethiopia". In Sustaining the Soil: Indigenous Soil and Water Conservation in Africa, ed. I.S.C. Reij, Princeton Co., London

\begin{tabular}{llccccc}
\hline No & Kebele & $\begin{array}{c}\text { Altitude } \\
(\mathrm{m})\end{array}$ & $\begin{array}{c}\text { Household head } \\
\text { Population }\end{array}$ & $\begin{array}{c}\text { Total } \\
\text { population }\end{array}$ & Area (ha) & $\begin{array}{c}\text { Density } \\
\text { /ha }\end{array}$ \\
\hline 1 & $\begin{array}{l}\text { Aratber } \\
\text { mukere }\end{array}$ & 2090 & 566 & 5203 & 888 & 5.86 \\
2 & $\begin{array}{l}\text { Danecho } \\
\text { Mukere }\end{array}$ & $2418-3023$ & 981 & 9307 & 1477 & 6.30 \\
& & & & & \\
3 & Weliya & 2110 & 401 & 3800 & 600 & 6.33 \\
4 & Anshebeso & 2266 & 864 & 8211 & 1285 & 6.40 \\
\hline \multicolumn{5}{l}{ Source: Woreda Agricultural and Rural Development Office, 2010} \\
\end{tabular}

Table 2 Share of the Sample Population

\begin{tabular}{lcccccc}
\hline & Total members & \multicolumn{4}{c}{ share of samples } \\
Kebele & $\mathrm{M}$ & $\mathrm{F}$ & $\mathrm{T}$ & $\mathrm{M}$ & $\mathrm{F}$ & $\mathrm{T}$ \\
\hline Aratber mukere & 384 & 182 & 566 & 19 & 5 & 24 \\
Danecho mukere & 808 & 173 & 981 & 35 & 7 & 42 \\
Welia & 355 & 46 & 401 & 13 & 4 & 17 \\
Anshebeso & 628 & 236 & 864 & 32 & 5 & 37 \\
Total & 2175 & 637 & 2812 & 99 & 21 & 120 \\
Source: Woreda & Agricultural & and & Rural & Development & Office, & 2010
\end{tabular}


Table 3 Hurni's (1985) USLE Application Factors in the Study Area

\begin{tabular}{llcc}
\hline Elements & Description (value) & Factors & Factor value \\
\hline Rainfall $(\mathrm{mm})$ & 1435.6 & $\mathrm{R}$ & 789.6 \\
Soil color & Red & $\mathrm{K}$ & 0.25 \\
Slope length $(\mathrm{m})$ & 160 & $\mathrm{~L}$ & 2.7 \\
Slope gradient & $42 \%$ & $\mathrm{~S}$ & 4.30 \\
Land cover & Degraded land & $\mathrm{C}$ & 0.05 \\
Management & No tillage & $\mathrm{P}=114.59$ & 1.00 \\
A= R X K X L X S X C X P & \multicolumn{2}{r}{$=11$} \\
\hline
\end{tabular}

Table 4 Indigenous and Improved Soil Conservation Structure Applied by Respondents

\begin{tabular}{lcccc}
\hline $\begin{array}{l}\text { Types of SWC } \\
\text { structures }\end{array}$ & $\begin{array}{c}\text { Indigenous SWC } \\
\text { structure }\end{array}$ & $\begin{array}{c}\text { Improved SWC } \\
\text { structure }\end{array}$ & \multicolumn{2}{c}{ Total } \\
Count & $\%$ \\
\hline $\begin{array}{l}\text { Contour plowing and cut } \\
\text { off- drain }\end{array}$ & $\checkmark$ & - & 16 & 13.3 \\
Soil /stone bunds & $\checkmark$ & $\checkmark$ & 13 & 10.8 \\
Fanya juu & - & $\checkmark$ & 5 & 4.2 \\
Cutoff drains & $\checkmark$ & $\checkmark$ & 6 & 5.0 \\
Planting of trees & $\checkmark$ & $\checkmark$ & 9 & 7.5 \\
Fallowing & $\checkmark$ & - & 29 & 24.2 \\
Leaving crop residues & $\checkmark$ & - & 6 & 5.0 \\
Application of manure & $\checkmark$ & - & 26 & 21.7 \\
Drainage ditches & $\checkmark$ & - & 10 & 8.3 \\
\hline
\end{tabular}

Table 5 Farmers' Response to Soil Erosion Problem by Degree of Severity

\begin{tabular}{lcccccc}
\hline $\begin{array}{l}\text { Degree of severity } \\
\text { of erosion }\end{array}$ & \multicolumn{4}{c}{ SWC practices } & \multicolumn{3}{c}{ Total sample } \\
& Implemented (74) & Not implemented (46) & \multicolumn{2}{c}{$(\mathrm{N}=120)$} \\
& Count & $\%$ & Count & $\%$ & Count & $\%$ \\
\hline Minor & 12 & 16.2 & 24 & 52.2 & 36 & 30.0 \\
Moderate & 27 & 36.5 & 8 & 17.4 & 35 & 29.2 \\
Severe & 21 & 28.4 & 11 & 23.9 & 32 & 26.7 \\
Very severe & 14 & 18.9 & 3 & 6.5 & 17 & 14.1 \\
Total & 74 & 100.0 & 46 & 100.0 & 120 & 100.0 \\
\hline
\end{tabular}


Table 6 Slope of Cultivated Lands of Respondents

\begin{tabular}{|c|c|c|c|c|c|c|}
\hline \multirow{3}{*}{$\begin{array}{l}\text { Degree of steepness } \\
\text { of plots }\end{array}$} & \multicolumn{4}{|c|}{ SWC practices } & \multirow{2}{*}{\multicolumn{2}{|c|}{$\begin{array}{l}\text { Total sample } \\
(\mathrm{N}=120)\end{array}$}} \\
\hline & \multicolumn{2}{|c|}{ Implemented (74) } & \multicolumn{2}{|c|}{ Not implemented (46) } & & \\
\hline & Count & $\%$ & Count & $\%$ & Count & $\%$ \\
\hline Flat /no slope & 6 & 8.10 & 11 & 23.9 & 17 & 14.2 \\
\hline Gentle & 14 & 18.9 & 19 & 41.3 & 33 & 27.5 \\
\hline Moderate & 43 & 58.1 & 13 & 28.3 & 56 & 46.7 \\
\hline Steep & 11 & 14.9 & 3 & 6.5 & 14 & 11.6 \\
\hline
\end{tabular}

Table 7 Farmers' Response to Yield, Farming and Soil Fertility Management

\begin{tabular}{|c|c|c|}
\hline \multirow[t]{2}{*}{ Farmers' response to } & \multicolumn{2}{|c|}{ Respondents $(\mathrm{N}=120)$} \\
\hline & Count & $\%$ \\
\hline \multicolumn{3}{|l|}{ Yield in unit area } \\
\hline - decreasing & 46 & 38.3 \\
\hline - unchanged & 20 & 16.7 \\
\hline - increasing & 54 & 45.0 \\
\hline \multicolumn{3}{|c|}{ Size of agricultural land cultivated over time } \\
\hline - decreasing & 79 & 65.8 \\
\hline - unchanged & 32 & 26.7 \\
\hline - in creasing & 9 & 7.5 \\
\hline \multicolumn{3}{|c|}{ Current land holding to support the family } \\
\hline - insufficient & 81 & 67.5 \\
\hline - $\quad$ sufficient & 36 & 32.5 \\
\hline \multicolumn{3}{|c|}{$\begin{array}{l}\text { Measures taken to enhance the declining fertility } \\
\text { of the farm land }\end{array}$} \\
\hline - crop rotation & 107 & 26.1 \\
\hline - $\quad$ shift to other land & 2 & 0.5 \\
\hline - $\quad$ using manure & 74 & 18.0 \\
\hline - $\quad$ expand the farm land & 6 & 1.5 \\
\hline - $\quad$ use fertilizer & 104 & 25.4 \\
\hline - $\quad$ change land use type & 11 & 2.7 \\
\hline - $\quad$ fallowing & 42 & 10.2 \\
\hline - others & 64 & 15.6 \\
\hline
\end{tabular}


Table 8 Farmers Response to Causes of Soil Erosion and Decline Productivity

\begin{tabular}{lcc}
\hline Farmers' response to & Respondents (N=120 ) \\
& Count & $\%$ \\
\hline Causes of soil erosion & 4 & 3.3 \\
- overgrazing & 11 & 9.2 \\
- poor agricultural practice & 22 & 18.3 \\
- $\quad$ ever cultivation & 62 & 51.7 \\
- cultivation of steep slope & 21 & 17.5 \\
Cause of productivity decline & & \\
- frequent cultivation & 54 & 23.2 \\
- soil erosion un reliable rainfall & 81 & 34.8 \\
- high price of fertilizer & 66 & 28.3 \\
Causes for the size of agricultural land decline & 4 & 1.7 \\
- family (population ) increase & 28 & 12.0 \\
- it was sold due to poverty & 56 & $57 \%$ \\
- land degradation & 36 & 36.7 \\
\hline
\end{tabular}

Table 9 Farmers' Response to the Problems of Conservation Structures

\begin{tabular}{lcccc}
\hline Identified problem & \multicolumn{4}{c}{ Farmer's response to selected structures (\%) } \\
& $\begin{array}{l}\text { Stone /soil } \\
\text { bunds }\end{array}$ & $\begin{array}{c}\text { Cut off } \\
\text { drains }\end{array}$ & Water ways & Fanya Juu \\
& 4.2 & 36.7 & 39.2 & 1.7 \\
\hline Costly & 8.3 & 28.3 & 35.8 & 10.0 \\
Difficult to implement & 17.5 & 21.7 & 11.7 & 24.2 \\
Labour intensive & 23.3 & 3.3 & 5.0 & 22.5 \\
Difficult to turn oxen & 31.7 & 9.2 & 6.7 & 32.5 \\
Reduce farm land & - & 0.8 & 1.7 & 1.7 \\
No problem at all & & & & \\
\hline
\end{tabular}

